\title{
Characterization of Enterobacter cloacae and $E$. sakazakii by Electrophoretic Polymorphism of Acid Phosphatase, Esterases, and Glutamate, Lactate and Malate Dehydrogenases
}

\author{
By PH. GOULLET* AND B. PICARD \\ Laboratoire de Microbiologie, Faculté de Médecine Xavier-Bichat (Université Paris VII), \\ 16 rue Henri Huchard, 75018 Paris, France
}

(Received 25 March 1986; revised 17 June 1986)

Acid phosphatase, esterases, and glutamate, lactate and malate dehydrogenases of 34 strains of Enterobacter cloacae and 22 strains of Enterobacter sakazakii were analysed by horizontal polyacrylamide agarose gel electrophoresis and by isoelectrofocusing in thin-layer polyacrylamide gel. The two species could be separated on the basis of distinct electrophoretic patterns of all enzymes analysed. Glutamate dehydrogenase and acid phosphatase were detected exclusively in E. cloacae, whereas esterase bands were more intensively stained in E. sakazakii. For each species, two zymotypes could be distinguished, on the basis of electrophoretic mobilities of malate dehydrogenase and banding patterns of esterase for $E$. cloacae, and by both isoelectric point and electrophoretic mobilities of an esterase and of lactate and malate dehydrogenases for E. sakazakii. The high degree of enzyme polymorphism within the two species permitted precise identification of strains. The variations in electrophoretic patterns might therefore provide useful epidemiological markers.

\section{INTRODUCTION}

Enterobacter cloacae, which may be isolated from human and animal faeces, is an opportunistic pathogen responsible for nosocomial infections. Enterobacter sakazakii (Farmer et al., 1980), formerly known as yellow pigmented $E$. cloacae, has been isolated from sputum, faeces, spinal fluid and blood (Farmer et al., 1980) and may cause neonatal meningitis (Muytjens et al., 1983). These two species, which form two distinct hybridization groups (Steigerwalt et al., 1976; Farmer et al., 1980; Izard et al., 1983) were found to be phenotypically different in only a few biochemical tests (Farmer et al., 1980).

Recently, using both conventional electrophoresis (CE) and isoelectrofocusing (IEF), enzyme polymorphism has been used for specific and subspecific differentiation of bacteria (Goullet \& Picard, 1985a, b). Data obtained by the two procedures gave highly discriminative and reliable information, which reflected genetic divergence better than did biochemical tests (Picard \& Goullet, 1985).

The purpose of this study was to evaluate phenotypic differences between and within E. sakazakii and E. cloacae on the basis of electrophoretic and IEF profiles of acid phosphatase (AP), esterases (EST), and glutamate, lactate and malate dehydrogenases (GDH, LDH and $\mathrm{MDH})$.

\section{METHODS}

Strains and their cultivation. The names and sources of the test strains are given in Table 1. Bacteria were grown in Fernbach flasks containing $500 \mathrm{ml}$ Tryptic Soy Broth (Difco). Flasks were vigorously shaken at $37^{\circ} \mathrm{C}$ for $18 \mathrm{~h}$.

Electrophoretic analysis. Preparation of extracts, inhibition by di-isopropyl fluorophosphate (DFP), CE and

Abbreviations: AP, acid phosphatase; CE, conventional electrophoresis; EST, esterase; GDC, genetic diversity coefficient; GDH, glutamate dehydrogenase; IEF, isoelectrofocusing; LDH, lactate dehydrogenase; MDH, malate dehydrogenase; $M_{R}$, relative mobility. 
Table 1. Strains examined

A. Enterobacter cloacae

\begin{tabular}{|c|c|c|c|c|}
\hline $\begin{array}{l}\text { Laboratory } \\
\text { code }\end{array}$ & $\begin{array}{c}\text { Strain } \\
\text { designation* }\end{array}$ & Origin $†$ & $\begin{array}{l}\text { Laboratory } \\
\text { code }\end{array}$ & $\begin{array}{c}\text { Strain } \\
\text { designation }\end{array}$ \\
\hline 1 & $11.76^{a}$ & Stool; Versailles & 18 & $36.76^{b}$ \\
\hline 2 & $8.76^{a}$ & Blood; Paris & 19 & HB $8^{b}$ \\
\hline 3 & HB $2^{b}$ & Lung; Clichy & 20 & HB $4^{b}$ \\
\hline 4 & $7.76^{a}$ & Navel; Paris & 21 & $\mathrm{HB} 7^{b}$ \\
\hline 5 & $34.76^{a}$ & Pus; Lagny & 22 & HB $11^{b}$ \\
\hline 6 & HB $9^{b}$ & Urine; Clichy & 23 & $\mathrm{HB} \mathrm{l}^{b}$ \\
\hline 7 & $45.75^{a}$ & Frog; Turkey & 24 & $60.80^{a}$ \\
\hline 8 & HB $5^{b}$ & Lung; Clichy & 25 & HB $3^{b}$ \\
\hline 9 & HB $10^{b}$ & Urine; Clichy & 26 & $32.72^{a}$ \\
\hline 10 & $41.76^{a}$ & Dog; Blois & 27 & $44.80^{a}$ \\
\hline 11 & $9.76^{a}$ & Trachea; Paris & 28 & $26.76^{a}$ \\
\hline 12 & $10.76^{a}$ & Stool; Dakkar, Senegal & 29 & $34.75^{a}$ \\
\hline 13 & $61.80^{a}$ & Bile; Paris & 30 & $39.80^{a}$ \\
\hline 14 & $77.80^{a}$ & Blood; Paris & 31 & $50.75^{a}$ \\
\hline 15 & $78.80^{a}$ & Spinal fluid; Paris & 32 & $29.76^{a}$ \\
\hline 16 & $79.80^{a}$ & Catheter; Paris & 33 & $58.76^{a}$ \\
\hline 17 & $47.75^{a}$ & Starch & 34 & $29.75^{a}$ \\
\hline
\end{tabular}

B. Enterobacter sakazakii

$\begin{array}{cc}\begin{array}{c}\text { Laboratory } \\ \text { code }\end{array} & \begin{array}{c}\text { Strain } \\ \text { designation* }\end{array} \\ 35 & 3.85^{a} \\ 36 & 47.81^{a} \\ 37 & 20.77^{a} \\ 38 & 20.73^{a} \\ 39 & 3.74^{a} \\ 40 & 6.85^{a} \\ 41 & 4.74^{a} \\ 42 & 12.82^{a} \\ 43 & 14.82^{a} \\ 44 & 19.82^{a} \\ 45 & 36.82^{a}\end{array}$

\begin{tabular}{lccl}
\multicolumn{1}{c}{ Origin $\dagger$} & $\begin{array}{c}\text { Laboratory } \\
\text { code }\end{array}$ & $\begin{array}{c}\text { Strain } \\
\text { designation* }\end{array}$ & \multicolumn{1}{c}{ Origin $\dagger$} \\
Water; Charenton & 46 & $2.85^{a}$ & Urine; Clermont Ferrand \\
Pus; Spain & 47 & $38.76^{a}$ & Blood; Paris \\
Stool; Paris & 48 & $4.85^{a}$ & Stool; Chateauroux \\
Sputum; Toulon & 49 & $33.83^{a}$ & Pus; Brest \\
Stool; Drancy & 50 & $31.81^{a}$ & Blood; Amiens \\
Bird; Paris & 51 & $53.82^{a}$ & Sausage; Paris \\
Urine; Paris & 52 & $81.84^{a}$ & Stool; Paris \\
Spinal fluid; Poissy & 53 & $14.77^{a}$ & Pus; St Etienne \\
Nose; Poissy & 54 & $36.77^{a}$ & Pus; Paris \\
Stool; Poissy & 55 & $17.74^{a}$ & Water; Belgium \\
Stool; Poissy & 56 & $7.75^{a}$ & Tooth; Paris
\end{tabular}

* $a$, Strains from the collection of Service des Enterobacteries (Professeur Le Minor), Institut Pasteur, Paris, France, and provided by $\operatorname{Dr} \mathrm{C}$. Richard; $b$, strains isolated at Beaujon Hospital, France.

$\dagger$ Country of origin France unless otherwise stated.

IEF, establishment of correspondence of bands characterized in the two electrophoretic techniques and esterase staining, were done as described by Goullet (1973) and Goullet \& Picard (1985a). Staining methods for the other enzymes were as follows: GDH, Baptist et al. (1969); LDH and MDH, Siciliano \& Shaw (1976); AP, Uriel (1963). The electrophoretic mobility of a given variant was measured as the relative mobility value $\left(M_{R}\right)$ (Goullet \& Picard, 1985b) which is the ratio between the distance measured from the slower band (GDH of $E$. cloacae strain 45.75) to the band of the variant and the distance measured from the slower band to the faster band (esterase $\mathrm{ES}_{1}$ of E. sakazakii strain 20.77).

\section{RESULTS}

\section{Characterization of enzyme bands}

$I E F$. Satisfactory resolution with distinct banding was obtained for MDH and LDH of $E$. cloacae and E. sakazakii, for AP of E. cloacae and for an esterase of E. sakazakii. Esterases of $E$. cloacae, AP of E. sakazakii and GDH of E. cloacae and E. sakazakii were not detected. With a narrow pH gradient from 4 to 6.5, MDH and AP gave a sharp and well-stained main band (used for pI determination) and two or three anodic satellite bands. LDH generally gave three bands (the one nearest the cathode was used for $\mathrm{pI}$ determination), whereas esterase gave a single band (Figs 1 and 2). 
(a)

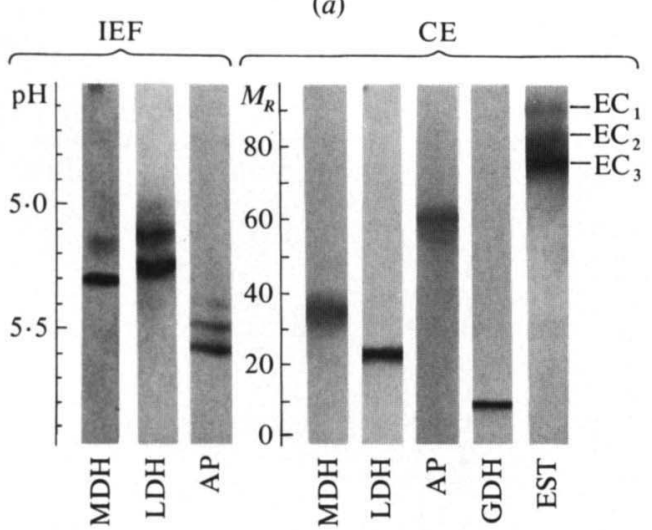

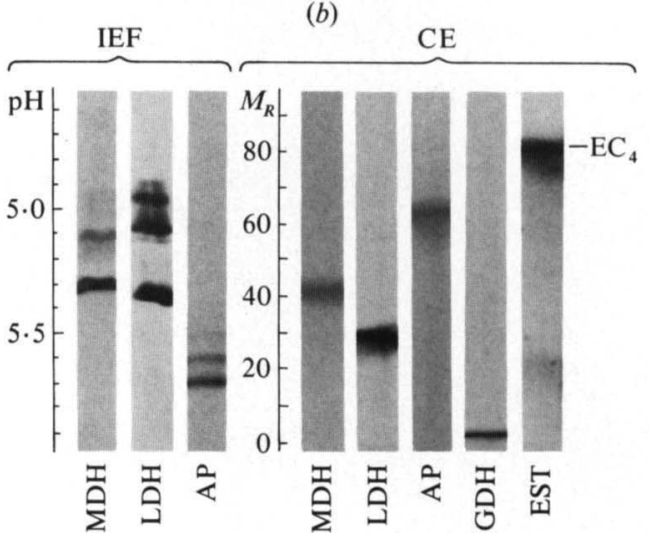

Fig. 1. Zymograms of E. cloacae. (a) Strain 14 from zymotype $\mathrm{C}_{1} ;\left(\right.$ b) strain 33 from zymotype $\mathrm{C}_{2}$. Esterase $\mathrm{EC}_{5}$, which migrated towards the cathode, is not shown.

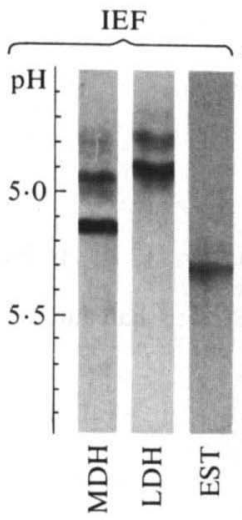

strain 39 the range and esterase $\mathrm{ES}_{4}$. (a)

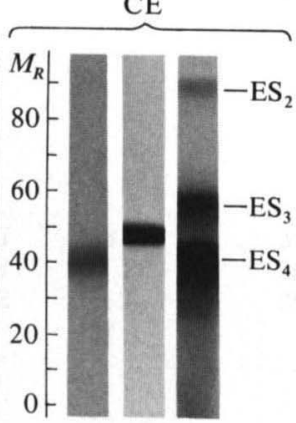

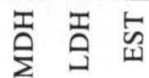

(b)
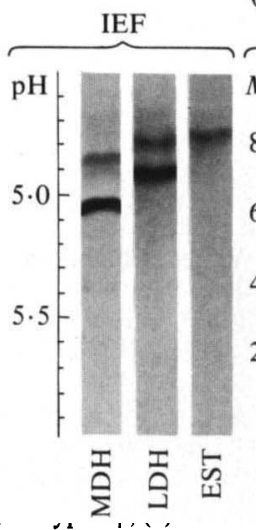
$\mathrm{CE}$

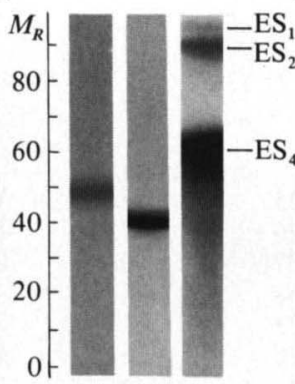

要党点

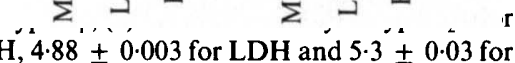

Polyacrylamide agarose gel electrophoresis. This method was more sensitive than IEF for detecting the enzymes, all of which gave reproducible banding patterns. MDH, LDH, GDH and AP gave a single, well-stained band, but GDH and AP were detected only in $E$. cloacae (Figs 1 and 2). Diverse esterase bands, all of which degraded $\alpha$-naphthyl acetate (numbered in order of decreasing mobility towards the anode) could be distinguished on the basis of their hydrolytic activity towards other substrates ( $\beta$-naphthyl and indoxyl acetates, and $\alpha$ - and $\beta$-naphthyl butyrates), and in their sensitivity or resistance to DFP $\left(10^{-3} \mathrm{M}\right)$ (Table 2). For E. cloacae strains, esterase band $\mathrm{EC}_{1}$ hydrolysed indoxyl acetate; band $\mathrm{EC}_{2}$ did not hydrolyse other substrates; band $\mathrm{EC}_{3}$ hydrolysed $\beta$-naphthyl acetate; band $\mathrm{EC}_{4}$ hydrolysed $\alpha$-naphthyl butyrate and indoxyl acetate and reacted slightly with $\beta$-naphthyl acetate; and band $\mathrm{EC}_{5}$ (migrating to the cathode) hydrolysed $\beta$-naphthyl acetate. Esterases $\mathrm{EC}_{1}$ and $\mathrm{EC}_{3}$ were resistant to DFP whereas esterases $\mathrm{EC}_{2}, \mathrm{EC}_{4}$ and $\mathrm{EC}_{5}$ were sensitive. Except for esterase $\mathrm{EC}_{4}$, the bands resolved from crude extracts of $E$. cloacae were faint. For $E$. sakazakii, esterase bands $E_{1}$, which hydrolysed indoxyl acetate, and $\mathrm{ES}_{2}$, which hydrolysed $\beta$-naphthyl acetate and $\alpha$ - and $\beta$-naphthyl butyrates, were resistant to DFP; band $\mathrm{ES}_{3}$ hydrolysed indoxyl acetate and $\alpha$-naphthyl butyrate; band $\mathrm{ES}_{4}$, which was identified as the esterase obtained by IEF, strongly hydrolysed $\alpha$ - and $\beta$-naphthyl acetates and indoxyl acetate, and reacted weakly with $\alpha$-naphthyl butyrate. Esterases $\mathrm{ES}_{3}$ and $\mathrm{ES}_{4}$ were sensitive to DFP. 
Table 2. Hydrolytic activity and sensitivity to DFP $\left(10^{-3} \mathrm{M}\right)$ of esterase bands of E. cloacae and E. sakazakii

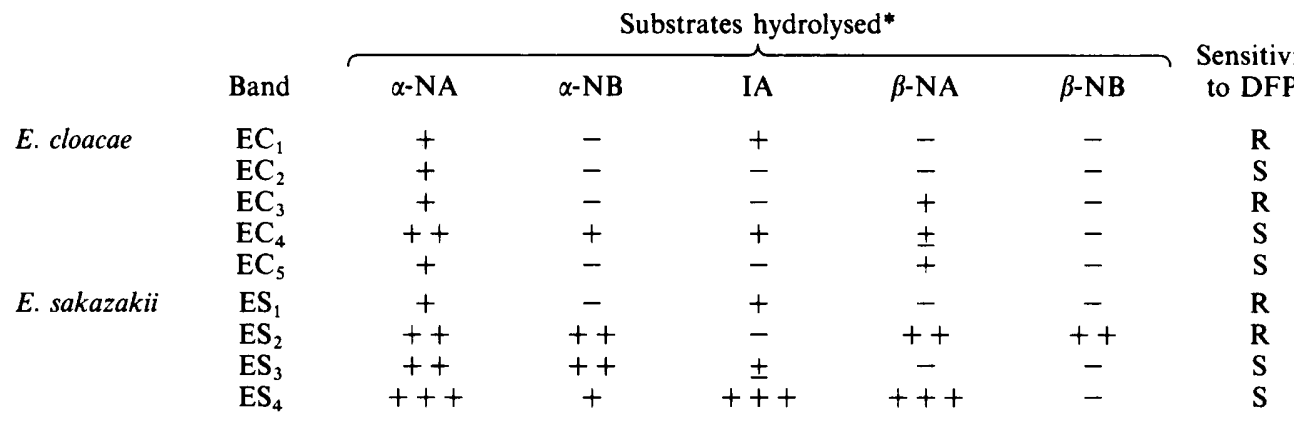

* $\alpha$-NA, $\alpha$-naphthyl acetate; $\alpha$-NB, $\alpha$-naphthyl butyrate; IA, indoxyl acetate; $\beta$-NA, $\beta$-naphthyl acetate; $\beta$-NB, $\beta$-naphthyl butyrate. +++ , Intensively stained band; ++ , moderately stained band; + , faint band; \pm , very weak activity; - , no activity.

$\dagger R$, resistant; $S$, sensitive.

Table 3. $p I$ and $M_{R}$ values of enzyme bands in strains of $E$. cloacae

For enzyme abbreviations see text.

\begin{tabular}{|c|c|c|c|c|c|c|c|c|c|c|}
\hline & & & $M_{R}$ valu & & & & & alues & & \\
\hline & code & MDH & LDH & AP & GDH & $\mathrm{EC}_{1}$ & $\mathrm{EC}_{2}$ & $\mathrm{EC}_{3}$ & $\mathrm{EC}_{4}$ & $\mathrm{EC}_{5}$ \\
\hline Zymotype $\mathrm{C}_{1}$ & 1 & $5 \cdot 3 / 35$ & $5 \cdot 35 / 26$ & $5 \cdot 9 / 60$ & 5 & 89 & - & 48 & - & - \\
\hline & 2 & $5 \cdot 3 / 35$ & $5 \cdot 35 / 29$ & $5.9 / 55$ & 5 & 89 & - & 48 & - & - \\
\hline & 3 & $5 \cdot 3 / 35$ & $5 \cdot 35 / 29$ & $5.85 / 55$ & 3 & 96 & - & - & - & -34 \\
\hline & 4 & $5 \cdot 3 / 35$ & $5 \cdot 35 / 29$ & $5.85 / 59$ & 4 & 89 & - & 48 & - & - \\
\hline & 5 & $5 \cdot 3 / 35$ & $5 \cdot 35 / 29$ & $5.8 / 59$ & 4 & 96 & 83 & - & - & -34 \\
\hline & 6 & $5 \cdot 3 / 35$ & $5 \cdot 35 / 29$ & $5 \cdot 6 / 55$ & 7 & 96 & - & 85 & - & -34 \\
\hline & 7 & $5 \cdot 3 / 35$ & $5.35 / 29$ & $5.6 / 59$ & 0 & 92 & 82 & - & - & -34 \\
\hline & 8 & $5 \cdot 3 / 35$ & $5 \cdot 35 / 29$ & $5 \cdot 6 / 60$ & 3 & 96 & - & - & - & - \\
\hline & 9 & $5 \cdot 3 / 35$ & $5 \cdot 35 / 29$ & $5 \cdot 6 / 60$ & 5 & 96 & - & - & - & -34 \\
\hline & 10 & $5 \cdot 3 / 35$ & $5 \cdot 35 / 30$ & $5 \cdot 6 / 60$ & 4 & 96 & 83 & - & - & -34 \\
\hline & 11 & $5 \cdot 3 / 35$ & $5 \cdot 30 / 26$ & $5 \cdot 9 / 60$ & 0 & 89 & - & 48 & - & - \\
\hline & 12 & $5 \cdot 3 / 35$ & $5 \cdot 25 / 23$ & $6 \cdot 1 / 55$ & 7 & 96 & - & 75 & - & -34 \\
\hline & 13 & $5 \cdot 3 / 35$ & $5 \cdot 25 / 23$ & $5 \cdot 6 / 60$ & 5 & 94 & - & - & - & -34 \\
\hline & 14 & $5 \cdot 3 / 35$ & $5 \cdot 25 / 23$ & $5 \cdot 6 / 60$ & 7 & 92 & 83 & 75 & - & -34 \\
\hline & 15 & $5 \cdot 3 / 35$ & $5 \cdot 25 / 23$ & $5 \cdot 6 / 60$ & 7 & 92 & 83 & 75 & - & -34 \\
\hline & 16 & $5 \cdot 3 / 35$ & $5 \cdot 25 / 26$ & $5.95 / 55$ & 5 & - & 93 & - & - & - \\
\hline & 17 & $5 \cdot 3 / 35$ & $5 \cdot 25 / 26$ & $5 \cdot 6 / 49$ & 5 & 96 & 77 & - & - & - \\
\hline & 18 & $5 \cdot 3 / 35$ & $5 \cdot 2 / 23$ & $5 \cdot 6 / 59$ & 4 & 96 & - & 75 & - & -34 \\
\hline & 19 & $5 \cdot 3 / 35$ & $5 \cdot 2 / 23$ & $5 \cdot 6 / 59$ & 7 & 96 & - & 85 & - & -34 \\
\hline & 20 & $5 \cdot 3 / 35$ & $5 \cdot 2 / 23$ & $5 \cdot 6 / 60$ & 3 & 88 & - & 71 & - & -34 \\
\hline & 21 & $5 \cdot 3 / 35$ & $5 \cdot 2 / 23$ & $5 \cdot 6 / 60$ & 4 & 92 & 83 & 75 & - & -34 \\
\hline & 22 & $5 \cdot 3 / 35$ & $5 \cdot 2 / 23$ & $5 \cdot 6 / 60$ & 5 & 92 & - & 68 & - & -34 \\
\hline & 23 & $5 \cdot 3 / 35$ & $5 \cdot 2 / 23$ & $5.4 / 67$ & 7 & 96 & - & 85 & - & -34 \\
\hline & 24 & $5 \cdot 3 / 35$ & $5 \cdot 2 / 29$ & $5.85 / 59$ & 4 & 96 & 85 & - & - & -34 \\
\hline & 25 & $5 \cdot 3 / 35$ & $5 \cdot 2 / 29$ & $5 \cdot 8 / 56$ & 5 & 96 & - & 85 & - & -34 \\
\hline & 26 & $5 \cdot 3 / 35$ & $5 \cdot 2 / 29$ & $5 \cdot 6 / 60$ & 4 & 96 & - & 85 & - & -41 \\
\hline & 27 & $5 \cdot 3 / 35$ & $5 \cdot 2 / 29$ & $5 \cdot 6 / 60$ & 4 & 96 & - & 85 & - & -34 \\
\hline & 28 & $5 \cdot 3 / 35$ & $5.05 / 29$ & $5 \cdot 6 / 59$ & 4 & 90 & 85 & - & - & -34 \\
\hline & 29 & $5 \cdot 3 / 35$ & $5.05 / 29$ & $5 \cdot 6 / 63$ & 4 & 88 & 85 & - & - & -34 \\
\hline Zymotype $\mathrm{C}_{2}$ & 30 & $5 \cdot 3 / 42$ & $5 \cdot 35 / 29$ & $5 \cdot 8 / 59$ & 3 & 83 & - & - & 70 & - \\
\hline & 31 & $5 \cdot 3 / 42$ & $5.35 / 29$ & $5.75 / 63$ & 3 & - & - & - & 81 & - \\
\hline & 32 & $5 \cdot 3 / 42$ & $5 \cdot 35 / 29$ & $5 \cdot 7 / 63$ & 3 & - & - & - & 81 & - \\
\hline & 33 & $5 \cdot 3 / 42$ & $5 \cdot 35 / 29$ & $5 \cdot 7 / 63$ & 3 & - & - & - & 81 & - \\
\hline & 34 & $5 \cdot 3 / 42$ & $5 \cdot 35 / 29$ & $5 \cdot 5 / 67$ & 3 & - & - & - & 81 & - \\
\hline
\end{tabular}


Table 4. pI and $M_{R}$ values of enzyme bands in strains of E. sakazakii

For enzyme abbreviations see text.

\begin{tabular}{|c|c|c|c|c|c|c|c|}
\hline & \multirow{2}{*}{$\begin{array}{l}\text { Strain } \\
\text { code }\end{array}$} & \multicolumn{3}{|c|}{$\mathrm{pI} / M_{R}$ values } & \multicolumn{3}{|c|}{$M_{R}$ values } \\
\hline & & $\mathrm{MDH}$ & LDH & $\mathrm{ES}_{4}$ & $\mathrm{ES}_{1}$ & $\mathrm{ES}_{2}$ & $\mathrm{ES}_{3}$ \\
\hline \multirow{18}{*}{ Zymotype $S_{1}$} & 35 & $5 \cdot 15 / 41$ & $4.9 / 34$ & $5 \cdot 35 / 53$ & 96 & 92 & - \\
\hline & 36 & $5 \cdot 15 / 41$ & $4.9 / 34$ & $5 \cdot 2 / 57$ & - & 81 & - \\
\hline & 37 & $5 \cdot 15 / 41$ & $4.9 / 48$ & $5 \cdot 35 / 56$ & 100 & 79 & - \\
\hline & 38 & $5 \cdot 15 / 41$ & $4.9 / 48$ & $5 \cdot 3 / 44$ & 92 & - & 56 \\
\hline & 39 & $5 \cdot 15 / 41$ & $4.9 / 48$ & $5 \cdot 3 / 44$ & - & 92 & 56 \\
\hline & 40 & $5 \cdot 15 / 41$ & $4.9 / 48$ & $5 \cdot 3 / 56$ & - & - & - \\
\hline & 41 & $5 \cdot 15 / 41$ & $4.9 / 48$ & $5 \cdot 2 / 56$ & - & 92 & - \\
\hline & 42 & $5 \cdot 15 / 41$ & $4.9 / 48$ & $5 \cdot 2 / 56$ & - & 92 & - \\
\hline & 43 & $5 \cdot 15 / 41$ & $4.9 / 48$ & $5.2 / 56$ & - & 92 & - \\
\hline & 44 & $5 \cdot 15 / 41$ & $4.9 / 48$ & $5 \cdot 2 / 56$ & - & 92 & - \\
\hline & 45 & $5 \cdot 15 / 41$ & $4.9 / 48$ & $5 \cdot 2 / 56$ & - & 92 & - \\
\hline & 46 & $5 \cdot 15 / 41$ & $4.9 / 48$ & $5.2 / 67$ & 98 & 92 & 56 \\
\hline & 47 & $5 \cdot 15 / 41$ & $4.9 / 48$ & $5 \cdot 1 / 62$ & - & 96 & 66 \\
\hline & 48 & $5 \cdot 15 / 41$ & $4.9 / 48$ & $4.85 / 56$ & 96 & 92 & 66 \\
\hline & 49 & $5 \cdot 15 / 41$ & $4.9 / 48$ & - & - & 92 & - \\
\hline & 50 & $5 \cdot 15 / 41$ & $4.9 / 49$ & $5 \cdot 3 / 44$ & - & 92 & 56 \\
\hline & 51 & $5 \cdot 15 / 41$ & $4.9 / 49$ & $5 \cdot 2 / 44$ & - & 92 & 56 \\
\hline & 52 & $5 \cdot 15 / 41$ & $4.9 / 49$ & $5 \cdot 2 / 44$ & - & 92 & 56 \\
\hline \multirow[t]{4}{*}{ Zymotype $S_{2}$} & 53 & $5.05 / 49$ & $4.9 / 42$ & $4 \cdot 75 / 62$ & 93 & 91 & - \\
\hline & 54 & $5.05 / 49$ & $4.9 / 42$ & $4 \cdot 75 / 62$ & 93 & 91 & - \\
\hline & 55 & $5.05 / 49$ & $4 \cdot 9 / 42$ & $4 \cdot 7 / 64$ & - & 90 & - \\
\hline & 56 & $5.05 / 49$ & $4.9 / 42$ & $4.7 / 64$ & 96 & 85 & - \\
\hline
\end{tabular}

Range of $p I$ and mobilities of enzyme bands among the strains

Electrophoretic relationships between the strains were established by numerous repeated runs comparing enzyme bands side by side on the same gel. The reproducibility of the results was confirmed in several ways as described by Picard \& Goullet (1985).

E. cloacae. $\mathrm{pI}$ and $M_{R}$ values of enzymes detected in all 34 strains are shown in Table 3. MDH, which had the same pI value (5.3) for all strains, had two mobility values $\left(M_{R} \simeq 35\right.$ and $M_{R} \simeq 42$ ). These served to divide strains into two zymotypes: $\mathrm{C}_{1}$ (strains 1 to 29 ) and $\mathrm{C}_{2}$ (strains 30 to 34 ). LDH had five distinct $\mathrm{pI}$ values ranging from 5.05 to 5.35 and four mobility values from $M_{R} \simeq 23$ to $M_{R} \simeq 30$. For zymotype $\mathrm{C}_{2}$, LDH had identical $\mathrm{pI}$ and $M_{R}$ values. AP had ten distinct $\mathrm{pI}$ values ranging from $5 \cdot 4$ to $6 \cdot 1$, and seven mobility values ranging from $M_{R} \simeq 49$ to $M_{R} \simeq 67$. GDH had five mobility values ranging from $M_{R} \simeq 0$ to $M_{R} \simeq 7$. For zymotype $\mathrm{C}_{2}$, GDH had identical $M_{R}$ values. Esterases gave two distinct banding patterns. For zymotype $\mathrm{C}_{1}$, esterase $\mathrm{EC}_{1}$ was the most frequently detected among the strains, esterase $\mathrm{EC}_{5}$ had the same mobility for 21 strains and esterase $\mathrm{EC}_{4}$ was not detected; zymotype $\mathrm{C}_{2}$ possessed esterase $\mathrm{EC}_{4}$ but not esterases $\mathrm{EC}_{2}, \mathrm{EC}_{3}$ and $\mathrm{EC}_{5}$. Thus, strains of zymotype $\mathrm{C}_{2}$ could be distinguished from those of zymotype $\mathrm{C}_{1}$ by differences in electrophoretic patterns of at least four enzymes.

E. sakazakii. $\mathrm{pI}$ and $M_{R}$ values of enzymes detected in all 22 strains are shown in Table 4 . Two zymotypes could be clearly distinguished among the strains by $\mathrm{pI}$ and/or mobilities of $\mathrm{MDH}$, LDH and esterase $\mathrm{ES}_{4}$. Zymotype $\mathrm{S}_{1}$ (strains 35 to 52) was characterized by a pI of $5 \cdot 15$ and $M_{R} \simeq 41$ for $\mathrm{MDH}, M_{R} \simeq 34, M_{R} \simeq 48$ and $M_{R} \simeq 49$ for $\mathrm{LDH}$ and by $\mathrm{pI}$ values ranging from 4.85 to 5.35 for esterase $\mathrm{ES}_{4}$. Zymotype $\mathrm{S}_{2}$ (strains 53 to 56) was characterized by a pI of 5.05 and $M_{R} \simeq 49$ for $\mathrm{MDH}$, by $M_{R} \simeq 42$ for $\mathrm{LDH}$ and by $\mathrm{pI}$ values of 4.7 and 4.75 for esterase $\mathrm{ES}_{4}$. Bands $E_{2}$ and $E_{4}$ were found in 20 and 21 strains, respectively, whereas $E_{1}$ and $E_{3}$ were each detected in only eight strains. 


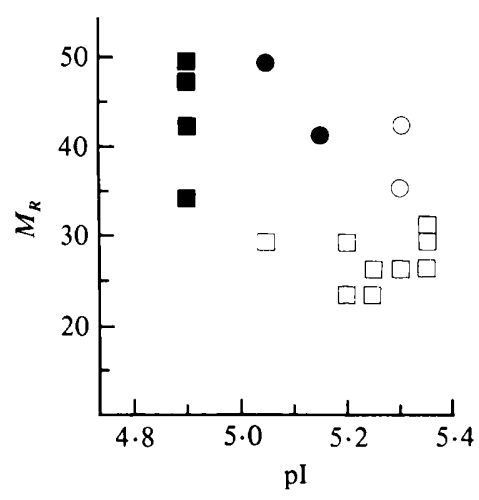

Fig. 3

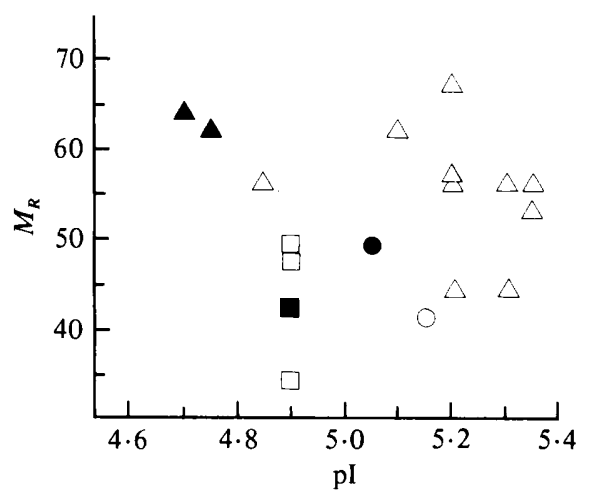

Fig. 4

Fig. 3. Two-dimensional electrophoretic profiles of LDH ( $\square$ ) and MDH (O) from E. cloacae and of LDH ( $(\mathbf{)})$ and MDH (O) from E. sakazakii. Each allozyme is defined by pI and $M_{R}$.

Fig. 4. Two-dimensional electrophoretic profiles of LDH ( $\square$ ), MDH (O) and esterase $\mathrm{ES}_{4}(\triangle)$ from $E$. sakazakii strains of zymotype $\mathrm{S}_{1}$ and of $\mathrm{LDH}(\square), \mathrm{MDH}(\mathrm{O})$ and esterase $\mathrm{ES}_{4}(\boldsymbol{\Lambda})$ from E. sakazakii strains of zymotype $S_{2}$. Each allozyme is defined by pI and $M_{R}$.

\section{DISCUSSION}

Using the zymogram procedure, LDH and MDH were resolved from crude extracts of both $E$. cloacae and E. sakazakii, whereas GDH and AP were detected only in E. cloacae. Several esterases were present in each of the two species. Except for esterases $\mathrm{EC}_{1}$ and $\mathrm{ES}_{1}$, which were similar in their hydrolytic activity and in their resistance to DFP, the esterases of E. sakazakii could be clearly distinguished from those of $E$. cloacae. Comparison of results obained by IEF and $\mathrm{CE}$ for esterases $\mathrm{ES}_{1}, \mathrm{ES}_{2}$ and $\mathrm{ES}_{3}$ of E. sakazakii and for esterases and $\mathrm{GDH}$ of E. cloacae, showed that CE was more sensitive than IEF for detection of enzyme activity (Tables 3 and 4), as has been already shown for some enzymes produced by Yersinia, Providencia and Aeromonas strains (Goullet \& Picard, 1984, 1985 b; Picard \& Goullet, 1985). The number of electrophoretic variants (allozymes) was higher with IEF (Table 5) for LDH and AP of E. cloacae and with CE for LDH of E. sakazakii. For LDH and AP of E. cloacae and for esterase $\mathrm{ES}_{4}$ of E. sakazakii, CE and IEF complement one another in the detection of electrophoretic enzyme variability. Conjunction of data obtained by the two techniques increased values of genetic diversity coefficients (GDC) (Nei, 1978; Musser et al., 1986) obtained by a single electrophoretic procedure (Table 5). The two hydrolases were more electrophoretically polymorphic than the two dehydrogenases. GDC values for esterase, AP and LDH were considerably higher than GDC values for MDH. As previously observed (Shah \& Williams, 1982; Goullet \& Picard, $1985 b$; Picard \& Goullet, 1985) MDH appears to be a useful molecular marker for both interand intra-species differentiation of bacteria.

Phenotypic differentiation of $E$. sakazakii from $E$. cloacae is principally based on nondiffusible yellow pigment production, absence of fermentation of D-sorbitol (Farmer et al., 1980; Richard, 1984) and detection of $\alpha$-glucosidase activity (Muytjens et al., 1984). By determining physico-chemical parameters of specific proteins the present work strongly consolidated this differentiation of the species. Thus, mobilities and pI values of either LDH or MDH were sufficient to identify to species level the 56 Enterobacter strains analysed. This is illustrated by two-dimensional electrophoretic profiles (Goullet \& Picard, 1985a), which clearly show that enzymes of $E$. sakazakii had lower pI values and/or higher $M_{R}$ values than $E$. cloacae (Fig. 3). Esterase patterns of the two species were distinct from those of Enterobacter aerogenes and Enterobacter gergoviae (Goullet, 1980).

As indicated by two-dimensional electrophoretic profiles of $\mathrm{LDH}, \mathrm{MDH}$ and esterase $\mathrm{ES}_{4}$ (Fig. 4), electrophoretic distribution of allozymes among $E$. sakazakii strains provided evidence 
Table 5. Numbers of allozymes $(a)^{*}$ and GDC values $\dagger$ for $M D H, L D H, A P$ and esterase $E S_{4}$ obtained by IEF, CE and by conjunction of the two techniques

\begin{tabular}{|c|c|c|c|c|c|c|c|}
\hline & & \multicolumn{2}{|c|}{ IEF } & \multicolumn{2}{|c|}{$\mathrm{CE}$} & \multicolumn{2}{|c|}{$\begin{array}{l}\text { Conjunction of } \\
\text { IEF and CE }\end{array}$} \\
\hline & & $a$ & GDC & $a$ & GDC & $a$ & GDC \\
\hline $\mathrm{MDH}$ & $\begin{array}{l}\text { E. cloacae } \\
\text { E. sakazakii }\end{array}$ & $\begin{array}{l}1 \\
2\end{array}$ & $\begin{array}{l}0 \\
0 \cdot 34\end{array}$ & $\begin{array}{l}2 \\
2\end{array}$ & $\begin{array}{l}0.25 \\
0 \cdot 34\end{array}$ & $\begin{array}{l}2 \\
2\end{array}$ & $\begin{array}{l}0.25 \\
0.34\end{array}$ \\
\hline $\mathrm{LDH}$ & $\begin{array}{l}\text { E. cloacae } \\
\text { E. sakazakii }\end{array}$ & $\begin{array}{l}5 \\
1\end{array}$ & $\begin{array}{l}0 \cdot 70 \\
0\end{array}$ & $\begin{array}{l}4 \\
4\end{array}$ & $\begin{array}{l}0.59 \\
0.66\end{array}$ & $\begin{array}{l}9 \\
4\end{array}$ & $\begin{array}{l}0.80 \\
0.66\end{array}$ \\
\hline AP & E. cloacae & 10 & 0.72 & 7 & 0.79 & 18 & 0.89 \\
\hline $\mathrm{ES}_{4}$ & E. sakazakii & 8 & 0.85 & 8 & 0.86 & 13 & 0.95 \\
\hline
\end{tabular}

* Including null allozymes.

$+\operatorname{GDC}(\mathrm{H})=1-\sum x_{i}^{2}[n /(n-1)]$ where $x_{i}$ is the frequency of each allozyme and $n$ is the number of strains in the samples calculated after deletion of strain 15 of E. cloacae and strains 43 to 45 of $E$. sakazakii (see Discussion).

for two zymotypes, $S_{1}$ and $S_{2}$. Combined use of IEF and CE was necessary to differentiate zymotypes defined on the basis of LDH or esterase $\mathrm{ES}_{4}$ patterns. Thus the LDH of the two zymotypes, which had the same $\mathrm{pI}$ value (4.9) for all strains, was resolved by $C E$ into variants with $M_{R}$ values of $\simeq 34, \simeq 48$ and $\simeq 49$ for zymotype $S_{1}$ and $M_{R} \simeq 42$ for zymotype $S_{2}$. Conversely, esterase $\mathrm{ES}_{4}$ of strain 47 (zymotype $\mathrm{S}_{1}$ ), and of strain 53 and 54 (zymotype $\mathrm{S}_{2}$ ), which had the same mobility for all strains, was resolved by IEF into variants with pI values of $5 \cdot 1$ and $4 \cdot 75$.

The high degree of enzyme polymorphism within E. cloacae and E. sakazakii enables precise identification of strains which may be useful for epidemiological purposes. For $E$. cloacae, all strains analysed had distinct electrophoretic patterns, with the exception of strains 14 and 15 which were isolated from two distinct clinical specimens (blood and spinal fluid) from the same patient. For E. sakazakii, strains $\mathbf{4 2}$ to 45 isolated from diverse sources in the same hospital had identical electrophoretic patterns (Table 3). This is strong evidence that these strains are identical.

The authors thank Doctor C. Richard for strains and Madame C. Gaillard and Madame N. Hautier for technical assistance. This work was supported by a grant from the Conseil Scientifique de la Faculté XavierBichat (Université Paris VII).

\section{REFERENCES}

Baptist, J. N., Shaw, C. R. \& MANDEl, M. (1969). Zone electrophoresis of enzymes in bacterial taxonomy. Journal of Bacteriology 99, 180-188.

farmer, J. J., III, Asbury, M. A., Hickman, F. W., Brenner, D. J. \& The ENTERobacteriaceae Study GROUP (1980). Enterobacter sakazakii: a new species of Enterobacteriaceae isolated from clinical specimens. International Journal of Systematic Bacterio$\operatorname{logy}$ 30, 569-584.

Goullet, PH. (1973). An esterase zymogram of Escherichia coli. Journal of General Microbiology 77, 27-35.

Goullet, PH. (1980). Distinctive electrophoretic patterns of esterases from Klebsiella pneumoniae, $K$. oxytoca, Enterobacter aerogenes and $E$. gergoviae. Journal of General Microbiology 117, 483-491.

Goullet, PH. \& Picard, B. (1984). Distinctive electrophoretic and isoelectric focusing patterns of esterases from Yersinia enterocolitica and Yersinia pseudotuberculosis. Journal of General Microbiology 130, 1471-1480.
Goullet, Ph. \& PiCARD, B. (1985a). A two-dimensional electrophoretic profile for bacterial esterases. Electrophoresis 6, 132-135.

Goullet, PH. \& PiCARD, B. (1985b). Etude du polymorphisme électrophoretique des lactate-, malate- et glutamate- deshydrogenases, de la phosphatase acide et des esterases de Providencia alcalifaciens, $P$. stuartii et $P$. rustigianii. Annales de l'Institut Pasteur/Microbiologie 136A, 347-358.

IZARD, D., RICHARD, C. \& LECLERC, H. (1983). DNA relatedness between Enterobcter sakazakii and other members of the genus Enterobacter. Annales de Microbiologie (Institut Pasteur) 134A, 241-245.

Musser, J. M., Barenkamp, S. J., Granoff, D. M. \& SELANDER, R. K. (1986). Genetic relationships of serologically nontypable and serotype b strains of Haemophilus influenzae. Infection and Immunity $\mathbf{5 2}$ 183-191.

Muytjens, H. L., Zanen, H. C., Sonderkamp, H. J., Kollee, L. A., Kaye Wachsmuth, I. \& Farmer, J. J., III (1983). Analysis of eight cases of neonatal 
meningitis and sepsis due to Enterobacter sakazakii. Journal of Clinical Microbiology 18, 115-120.

MuYtJens, H. L., VAN DER Ros-VAN DE REPE, J. \& VAN Druten, H. A. M. (1984). Enzymatic profiles of Enterobacter sakazakii and related species with special reference to the $\alpha$-glucosidase reaction and reproducibility of the test system. Journal of Clinical Microbiology 20, 684-686.

NEI, M. (1978). Estimation of average heterozygosity and genetic distance from a small sample of individuals. Genetics 89, 583-590.

Picard, B. \& Goullet, Ph. (1985). Comparative electrophoretic profiles of esterases, and of glutamate, lactate and malate dehydrogenases, from Aeromonas hydrophila, $A$. caviae and $A$. sobria. Journal of General Microbiology 131, 3385-3391.

RICHARD, C. (1984). Enterobacter. In Bergey's Manual of Systematic Bacteriology, 9th edn, vol. 1, pp. 465-
469. Edited by N. R. Krieg. Baltimore: Williams \& Wilkins

ShaH, H. N. \& Williams, R. A. D. (1982). Dehydrogenase patterns in the taxonomy of Bacteroides. Journal of General Microbiology 128, 2955-2965.

Siciliano, M. \& SHAW, C. R. (1976). Separation and visualization of enzymes on gels. In Chromatographic and Electrophoretic Techniques, 4th edn, vol. 2, pp. 185-209. Edited by I. Smith. Chicago: Yearbook Medical Publishers.

Steigerwalt, A. G., Fanning, G. R., Fife Asbury, M. A. \& BRENNer, D. J. (1976). DNA relatedness among species of Enterobacter and Serratia. Canadian Journal of Microbiology 22, 121-137.

URIEL, J. (1963). Caracterisation d'enzymes par électrophorèse en gélose. In Technique de Laboratoire, pp. 930-935. Edited by J. Loiseleur. Paris: Masson. 